\title{
Lessons from the History of Brucellosis
}

\author{
H.V. Wyatt \\ Visiting Lecturer in Philosophy, \\ University of Leeds
}

History reveals the past, but may foretell the future.

\section{Introduction}

For the British Royal Army Medical Corps, Brucellosis is the 'Corps Disease' - a battle honour in the war for better health. It was won by young doctors serving their first overseas postings to Malta more than one hundred years ago and continued by Maltese doctors like Colonel Vella and Vassallo.

As British servicemen began to serve in the Mediterranean after the Crimean War, many became ill with mysterious fevers known locally as Malta, Gibraltar or Cretan Fever, often confused with other fevers. In 1903 Bruce wrote to the Colonial Office that the official name be Mediterranean Fever, the name he had proposed in $1894 .{ }^{1}$

Although Malta Fever was too local, people clung to this older and shorter name. Nevertheless, he was able to use the official name for his Commission in 1904. Strangely, in all the papers which he edited for the Mediterranean Fever Commission [MFC], the Journal of the Royal Army Medical Journal [JAMC] and his papers in other journals, he always used Malta Fever. The newer name of Brucellosis is much better.

At the time of the Crimean War, there was much confusion about the diagnosis and cause of fevers, but in 1861 Dr Marston of the British Army described the many fevers seen in Malta in 1851. He gave a description of Typhoid Fever and distinguished it from Undulant Fever or what we now know as Brucellosis. In 1887 David Bruce, a young British Army doctor with Dr. Caruana Scicluna, the Maltese Public Health analyst, and Lady Bruce discovered and cultivated the micrococcus which caused the illness. Bruce never acknowledged the vital contribution that Caruana Scicluna had made to this research. ${ }^{2}$ But how people were infected remained a mystery although 'bad air' and drains were considered likely causes.

A significant advance was made by Professor Almoth Wright at the Army Medical School at Netley in England. He applied the Widal agglutination technique to distinguish Typhoid Fever from Undulant Fever by using cultures of bacteria and later with Surgeon Major Semple, dead bacteria. In 1904, Dr. Themistocles Zammit modified this test by examining the reaction on a slide with a microscope. Later he used this test, Zammit's Test, not only for serum, but also for milk.

Another young doctor, Captain Hughes, who was posted to Malta, wrote a monograph on the disease in 1897 which confirmed the previous discoveries, but prescribed goats' milk for patients' diet. This promising young researcher returned to Britain and was killed in the first months of the South African War in 1899.

At the end of the $19^{\text {th }}$ century, the British hospital in Valletta, housed in the Hospital of the Knights with its longest ward in Europe, was full of soldiers ill with the disease, many of whom were invalided to Britain. Nearly half were discharged for the complication of arthritis

\footnotetext{
${ }^{1}$ Wyatt, 'Give a disease a bad name,' [Filler] B. M.J. , no. 329, 2005, 272.

2 Wyatt, 'Dr. G. Caruana Scicluna' Journal of Medical Bio.g, no.8, 2000, 191-193.
} 
and their pensions were a serious drain on the British treasury. Bruce, now a Colonel and a Fellow of the Royal Society [FRS] continued to press for research into the disease and was appointed in 1904 to head the MFC with four researchers - with typical economy, no new salaries were necessary. Major Horrocks R.A.M.C. was to head the group in Malta with Staff Surgeon Shaw R.N., Dr. Johnson from the British Local Government Board and Dr. Themistocles Zammit, a keen Maltese bacteriologist working in the Government laboratory in Valletta. Later that year, another young doctor, Captain Crawford Kennedy, attending soldiers in the venereal diseases ward of the Valletta Hospital, joined the MFC.

The new discoveries of the role of insects in transmitting diseases dominated the early experiments. Hundreds of mosquitoes were allowed to feed on infected primates and were then examined. A very few were found to have been infected. Yet these results were surely to be expected because Malta had very few biting insects in the winter months when people continued to fall ill.

\section{Goats and the Royal Navy: the Silent Service}

Bruce had shown in 1888 that monkeys were susceptible to the disease and the MFC researchers used them in their studies. But monkeys were expensive and difficult to obtain. Bruce had visited Malta for a month in June - July 1904 and two weeks after he left, Shaw bought a nanny goat and a kid: both were negative by blood agglutination. Shaw injected the goat with the bacteria and noted a rise in temperature, but no illness. He injected it with more cultures, recorded further rises in agglutinin titres and tried to culture samples of milk and urine. Nothing grew from the urine and the milk samples were overgrown with Staphylococcus. He fed a monkey with milk from the infected goat, but the monkey died and its blood and organs yielded no colonies of the micrococcus. ${ }^{3}$

Shaw was unlucky and gave up, returning the goats to a farm. He wrote a paper with his results, but submitted it through the Admiralty, not through Bruce who knew nothing of his successful infection of the goat. He then withdrew it, possibly discouraged by the negative results of experiments by his naval colleagues. ${ }^{4}$ In May 1905 Bruce returned for a short visit to Malta and met Horrocks, Shaw and Zammit. Zammit wanted to continue with his experiments with goats (see below), but at first Bruce and Horrocks opposed this. Zammit persisted and was reluctantly allowed to buy some more goats. Shaw remained silent and did not support Zammit with his own results.

We do not know why Shaw began his experiments although his colleague Surgeon Gilmore R.N. had written to Bruce in 1904 that he wanted to feed a goat or two with milk. Gilmore was, however, forbidden to do any more animal experiments.

\section{Goats and Themistocles Zammit}

We are on surer ground with Zammit because he bought his two goats after spending a day with Caruana Scicluna. In 1903, Caruana Scicluna had seen that 'persons who lived on farms in which milch goats supplying milk' had fever and 'that the blood of a goat [...] strongly reacted to Remittent Fever [Brucellosis]'. I suggest that he told Zammit about these goats on $14^{\text {th }}$ September 1904 because Zammit bought his goat the next day and fed it agar cultures on the $18^{\text {th }}$ of the same month. No doubt Caruana Scicluna and Zammit thought that perhaps a few of the tens of thousands of goats were infected and that somehow the bacteria could be transferred to Man - perhaps by mosquitoes. Zammit fed his goat more cultures and noted its positive agglutinins and absence of illness. He noted the same responses in a second goat and found the bacteria in the urine, blood and milk of both goats. The day that Bruce left Malta, Zammit bought six more goats and discovered that five were positive. In the next few

\footnotetext{
3 Wyatt, 'Royal Navy surgeons and the transmission of Brucellosis by goats' milk,' JR N Med Service, no. 85, $1999,112-117$

${ }^{4}$ Ibid.
} 
weeks it was found that about half the goats on Malta were positive and about ten per cent were secreting bacteria in their milk. ${ }^{5}$

Although the discovery of the number of the infected goats was a surprise, even to Zammit, he had consistently pursued the disease by epidemiology, feeding and tests of blood and milk. He deserves credit for his discoveries. ${ }^{6}$

Following Zammit's discovery, Shaw examined the goats whose milk was bought for the R.N. Hospital at Bighi and banned those which were positive. All the milk was supposed to be boiled to destroy bacteria, but when the cauldron was nearly empty, more milk was added - and used before it had been sufficiently heated. The Military may give orders, but authority may be subverted - by intention or by laziness. A year later, there were still cases of Brucellosis and Shaw again examined the goats, finding that many were positive.

In 1906, the use of goats' milk by the British services was prohibited and the total of 3,631 cases in the previous six years was reduced to just 21 in 1907. Condensed, evaporated and sterilised milk were used instead. By 1909, the vast ward at the army hospital was empty and used for a huge reception and ball. ${ }^{7}$

\section{Transmission by sex}

In the Knights' hospital there was a Venereal Disease Ward (probably in the basement) under Captain Kennedy. He noticed that many of his patients were already suffering from Brucellosis when admitted. Keen to be part of the research, he applied to join the MFC and was told to begin research, but in addition to his present medical duties. Accompanied by a senior police officer he visited the prostitutes in the notorious Gut in Valletta - a street of low bars and even lower sexual haunts. The policeman may not have been to protect the women or Kennedy - but by his presence to persuade them that the visit was 'legal'. Kennedy found that thirty percent of 134 women were positive by the agglutination test although only 4 cases per thousand ordinary Maltese were reported so at that time. He went back to take urine samples and vaginal swabs and cervical mucus for culture, isolating colonies from four urines and two vaginal swabs. He also isolated Brucella from the vaginal swab, urine and milk from a married British woman. Kennedy transmitted the disease to two monkeys by attaching cotton wool soaked with infected urine around the glans. Kennedy reported these findings only in his M.D. thesis (for which he was awarded a Gold Medal). ${ }^{8}$

It would seem that the sex workers had acquired their infections from their male clients and that they then transmitted the disease to their next partners. But neither Kennedy nor others have examined semen from positive males to find the bacteria. Nor have I found reference to whether billy goat semen contains bacteria or whether nanny goats impregnated by positive billy goats were infected. It was known that the bacteria were found in the urine of cases and infected goats, so that it was possible that it might be also found in semen.

There was a clue to the sexual transmission in a long report in 1906 which listed several cases of Brucellosis among soldiers treated for sexual diseases (3 eg pages 196-199).

Kennedy also looked at products containing goats' milk. In Malta there were two kinds of ice-cream: the cheaper was little more than flavoured frozen goats' milk and might have been

\footnotetext{
5 Wyatt, 'How Themistocles Zammit found Malta Fever (Brucellosis) to be transmitted by the milk of goats,' $J$ Roy Soc Med , no.98, 2005, 451-454.

${ }^{6}$ Wyatt, 'Sir Themistocles Zammit; his honours and an annotated bibliography of his medical work,' Maltese Medical Journal, no.12, 2000, 27-30; Wyatt, A Tale of two goats and the fever transmitted by the milk of goats. Power point presentation with notes. 200; Wyatt, 'The curious affair of the identity of Fioravanti Sammut and Temistocle Zammit.' Journal of Med Biog, no. 19, 2011, 128-131.

${ }^{7}$ P. Cassar, Sir Themistocles Zammit and the controversy on the goat's role in the transmission of brucellosis (Mediterranean Fever) 1909-1916 (Government of Malta, 1981).

${ }^{8}$ Wyatt., 'Dr. James Crawford Kennedy RAMC and the sexual transmission of brucellosis,' J RAMC, no.155, 2009, 239-240.
} 
responsible for unexplained cases of the disease. The dearer, probably bought by officers, was a custard of milk and eggs, heated to near boiling and then frozen. A popular drink of sailors was grog, raw milk laced with rum: some bacteria might have survived their temporary immersion in alcohol. There was also an 'egg flip' made with goats' milk. Kennedy also looked at cheeses, etc.

Later, he examined milk in London and, comparing it with cultures obtained from Zammit in Malta, found that the milk contained Brucella agglutinins. This was the first clue to the relationship between Malta Fever and contagious abortion.

\section{Inhalation brucellosis}

Brucellosis must be the most easily acquired infection and almost all investigators of the disease have fallen ill with it. The Naval doctors Bassett-Smith and Shaw contracted the disease in 1900 and 1901. Captain Hughes was invalided to England in 1896 and his wife and her two sisters also contracted the disease in Malta. The members of the MFC were all ill at one time or another and almost all veterinarians have high anti-Brucella titres (see also 15). Sniffing of cultures was routine in diagnostic laboratories. Francois Jacob related that among the 'Pastorians [...] was the one to whom all France sent microbes that were hard to characterize, and who made his diagnosis by smell'. Sniffing of cultures is now forbidden. ${ }^{9}$

In the late $19^{\text {th }} \mathrm{C}$, ships of the Mediterranean Fleet called at ports in many countries. Although the crews had no contact with goats' milk, there were several epidemics of Brucellosis: in 1882 two ship epidemics accounted for $42 \%$ of the fleet cases. Captain Dudley R.N., Professor of Pathology at Greenwich examined the ships' diaries for the fleet and concluded that in the congested, humid, torrid and stifling atmosphere of the unventilated mess decks, 'Br melitensis had acquired the power of spreading by droplet infection'.

HMS Superb had 136 cases, 77 of whom were invalided home and one died. 'The ratings in the Superb slept on three decks. The flying deck was a kind of huge shelf cutting part of the lower deck horizontally in two.'

Table : Fever on HMS Superb.

$\begin{array}{lccc}\text { Deck } & \text { Ventilation } & \text { No. ratings } & \% \text { fever } \\ \text { Flying } & \text { worst, lowest cubic space per man } & 140 & 29 \\ \text { Lower } & & 196 & 17 \\ \text { Battery } & \text { better and relatively spacious } & 250 & 10\end{array}$

The epidemic was attributed to bad ventilation between decks. Dudley then reprinted the description of the lower deck in her sister ship:

'All the ship's company [ St Jean D'Acre ] amounting to about 930 men...slept on this deck. The hammock hooks were placed ordinarily at only 14 inches apart - less than the average breadth of the mens' shoulders; consequently while in harbour when no watch was required at night and all hands had turned in, they formed a compact mass close beneath the beams, the only air available for respiration being above them, that beneath the hammocks being almost entirely shut out from the space above. All the ports as well as the small round scuttles were kept closed at night.'

It was not only ships of the Royal Navy which had such unhealthy living quarters. With the threat posed by the newly formed Italian navy, monster muzzle -loading guns were installed at both Malta and Gibraltar. The battery at Fort Rinella, Malta had, like many of the forts of that time, underground quarters for the garrison. Conditions in the Lower St. Elmo barracks 'sunk in a hollow...were very insanitary $[\ldots]$ with very inadequate ventilation $[\ldots]$

${ }^{9}$ Wyatt, 'Surgeon Captain Sheldon F. Dudley R.N. and the person to person spread of brucellosis by inhalation,' $J$ R N Med Services, no 96, 2010, 185-187. 
the supply of fresh air a difficulty at all times and practically an impossibility in calm and still days. ${ }^{10}$ We know that captives today in the Middle East and elsewhere have been kept in far worse conditions than those of ships more than a century ago.

\section{The MFC}

The early work on Brucellosis was done by junior officers and it was the three juniors of the MFC, Shaw, Kennedy and Zammit, who made lasting contributions. The three seniors, Johnstone, Bruce and Horrocks contributed little - indeed Bruce and Horrocks tried to stop Zammit's researches on the goats. Horrocks returned to Gibraltar in 1905 and was replaced by a posse of RAMC majors and a Lt. Colonel. ${ }^{11}$

\section{Taste and Education}

The problem of transmission was solved, but convincing the Maltese was not so easy. They liked not only their goats, but also the taste of raw milk. In spite of an education drive from 1906, many Maltese refused to believe that their precious goats caused the disease. A local doctor and a pharmacist owned newspapers which questioned the role of the goats' milk in the transmission of the disease and were encouraged by a British doctor who visited Malta. The controversy lasted until 1916. ${ }^{12}$ In 1907 there were 714 cases among Maltese civilians and in general, the number of cases rose although there was a dramatic fall in the mid 1930's (as seen in hand-drawn Figure 1) when a decision was made to build a pasteurisation plant on Malta.

The Maltese were poor and could not afford refrigerators, although ice could be bought. Because milk bought in the morning would curdle by the afternoon, it was bought twice daily. Five thousand goats entered Valletta every morning and afternoon, their large udders trailing in the dirt, faeces and urine in the road. They were milked in the street into small jugs. Pint containers would be far too large and the project was only feasible when a waxed quarter pint container could be made. The new plant opened in May 1938. Goats were brought to covered milking yards and milked under supervision. The milk was weighed, cooled and taken in cans to the Milk Centre. Insulated electric vans were used for delivery, with ice to cool the one pint glass bottles and the smaller waxed cartons.

In 1927 there had been 699 cases of Brucellosis, rising to 1,909 in 1934. If the pasteurisation plant had been opened then, its success would have been obvious, for without it there were only 873 cases by $1936 .{ }^{13}$ The rise in the number of cases and the then dramatic fall could not have been caused by some change in the goats, but must surely have been due to subtle social changes among the Maltese or in the stricter adherence to the hygienic care of the goats. ${ }^{14}$

Today we would expect health authorities to examine why the measures to control the disease were not working - were the cases of farmers or café drinkers, from the villages or isolated houses, goat owners or milk buyers? In Malta, there was no money for such inquiry and few staff to carry out the routine measures to control the disease.

\footnotetext{
10 A.M. Davis, 'Report on the prevalence of Mediterranean Fever among British soldiers in Malta, 1905', Reports of the Mediterranean Fever Commission 1906, Part IV, 105-184.

${ }^{11}$ T.McCulloch, J.C., Weir J.C., F.H.A. Clayton, 'Epidemiological work in 1906,' Reports of the Mediterranean Fever Commission 1906, Part IV,105-184.

${ }^{12}$ Cassar (1981).

13 See Figure 1.

14 Anon.], Report on the health of the Maltese Islands for the year 1936, (Government of Malta, Malta, 1937) [National Archives of Malta, GMR.139].
} 


\section{Control}

Control was centred on three strategies, a vaccine, clean milk and healthy goats. Zammit and others tried to make an effective vaccine for humans, but were unsuccessful. Even if they had produced one, it would have been very difficult to protect a quarter of a million Maltese. In Malta, $90 \%$ of cases of poliomyelitis had been under 5 years, but when the Salk vaccine was used in 1957 and 1958, almost all those vaccinated were already immune to the major Type I and probably also to the other two types through avirulent strains. About 3,700 children under 5 were given 3 doses of the vaccine, nearly 8,000 from 5 to 9 years and 4,600 over 9 years. ${ }^{15}$ Unless they are registered and seen regularly by doctors or other health workers, it is very difficult to trace babies and children: it is easier to reach children in school than those younger and more in need.

At intervals, the authorities targeted the usual suspects - unhygienic living conditions and milking of the goats, the use of unboiled milk, the sale of infected milk and the presence of infected goats. Sadly, there were too few staff to enforce the regulations and the herdsmen were uncooperative.

From 1910, there were a few tests of milk samples and goats with positive milk were killed. Goats' milk that had not been boiled was banned from hotels and coffee shops, etc. Even though goats were prohibited, contraband milk was smuggled into the capital, Valletta. When goats were tested in a government centre, those positive for Brucellosis were to be slaughtered and compensation paid. However, staff returned the goats to the owner in exchange for half of the compensation.

After WW II malaria was eradicated from the island of Cyprus with the extensive use of DDT to kill the mosquitoes, showing that a determined campaign can succeed in ridding an island of a disease. In theory, Brucellosis could have been eradicated from Malta, but this did not happen. The testing of goats was limited by false positives and negatives, although, in time, these problems might have been overcome. The chief difficulty was the negative attitude of many of the Maltese and the owners of the goats. It was not until the 1960's that education, better communications and a higher standard of living meant that a serious effort at control could be made. Even health workers have to be aware of hygiene at all times: in Palestine, I saw goats on top of the waste bins happily chewing the soiled sanitary towels of the nursing students.

During the siege of the island in WWII many goats were eaten, but the Governor later ruefully commented that he wished all had been eaten. The use of pasteurised milk on Malta was a success and the ban on goats' milk was lifted for the British servicemen in early 1940. The partial success of pasteurisation and other measures on Malta had little effect on cases on Gozo. With one tenth of the population of Malta, as many as one half of the cases were from Gozo. Eventually a pasteurisation plant was built on Gozo.

From a low point in the war the number of cases rose to 2,410, but then fell rapidly to a few each year from 1965. In 1961 there were 31,000 goats on Malta, owned by 5,400 breeders of whom about 3,600 owned only one or two. These small breeders used the milk for their families, but often supplied neighbours and friends. From 1956, the government moved to eradicate Brucellosis from the goats and the few sheep, and tuberculosis from cattle. However, control of movement of goats was poor and there were many transfers to Gozo, previously free of disease. Even when herds were tested and infected animals were killed, there was no proper disinfection of the farms, so animals were reinfected. Many small herds were not registered or even found and farmers and breeders would not co-operate. Sheep and goats mingled when grazing and infected each other.

Other priorities ensured that the regulations were not rigorously enforced in the 1980's and the number of cases rose. A small outbreak in 1988 prompted new regulations and strict

\footnotetext{
15 H.V. Wyatt, 'Poliovaccines: lessons learnt and forgotten,' Hist Phil Life Science, no. 17, 1955, 91-112.
} 
enforcement with tattooing, branding and tagging of goats in 1,500 registered farms. Before an inspection, goats were transported by night to another herd, owned by a relative or neighbour. ${ }^{16}$ Eradication needed the help of vigilantes who would report on these transfers and the phantom herds.

\section{Cheese}

Kennedy had looked at the other milk products, ricotta and cheeselets (small cheeses) which could be fresh, dry or pickled. Ricotta, made from milk boiled with sea water, should be safe. The cheeselets should be made with sheep's milk and sheep were only very rarely infected. However, some were made with the addition of goats' milk which was occasionally infected (especially when the herdsman suspected that the goat was unwell). The brucella may survive for three months even in the dry cheeselets. The Milk Marketing Undertaking produced cheeselets with pasteurised milk, but home produced ones sold on the street were sometimes infected. Gozo produced more than Malta and some were exported to Malta.

The Compulsory Pasteurisation Regulations allowed the use of unpasteurised goats' milk for these cheeselets. In 1969, of 57 cases, 30 were from fresh cheeselets and only 11 were from direct contact with infected goats. By 1980 cheeselets had become very popular for weddings and other large events. Cases fell to about 5 or so each year, but cheeselets had become a large industry. In 1995 there was an epidemic with more than 232 identified cases (plus two cases in England who had been infected on a visit to Malta), of which 100 were treated in hospital. An intensive sampling and testing programme included every street vendor, grocer and supermarket. Raw milk from all registered herds was tested. Positive results were found from two unregistered herds, all goats of which were killed. Eventually all 3,416 herds on Malta and 1,449 on Gozo were screened and 68 cows, 116 goats and 43 sheep which were positive were killed. About a dozen illegal herds were discovered and their owners prosecuted. ${ }^{17}$

The epidemic finally ended in 1996 after new regulations were made and a massive education campaign reached the whole population. Probably the epidemic stemmed from three unregistered (phantom) herds which had been concealed.

Gradually the goats which may have numbered as many as 50,000, were replaced by cattle. I have never seen a cow on Malta as there is no grazing and the cows are kept in stalls. Fed with concentrated foods, the cows become constipated: Professor A. Scicluna-Spiteri proposed a porridge of newspapers (delivering digested news with the morning milk).

The 1988 regulations did not apply to goats kept only for family use. The Director of Agriculture, Professor A. Scicluna-Spiteri who had a degree in agriculture, made an order that all animals, including those privately owned, be registered and tested. Although the Chief Government Medical Officer is a medical doctor (and in future might be a medical scientist or a nurse?), administrators without an agriculture or science degree oversee the equally important agriculture post. Workers in health, food and agriculture (including animal husbandry) must work together in matters of health.

\section{Success}

In 2005, one hundred years after Zammit's experiments, Malta was finally declared free of Brucellosis. There had been partial successes over the previous years, but partial successes are in the long run a failure. The cost to Malta in those one hundred years of Brucellosis far exceeded the money which could have eradicated it. When asked in 1985, Maltese friends, middle class and educated, answered 'They used to say it had something to do with goats'. To eradicate a disease there must be an educated public, with public enthusiasm and commitment. The eradication of poliomyelitis in India has drawn on a million willing people

\footnotetext{
${ }^{16}$ J.R. Naudi J.R., Brucellosis. The Malta experience. A celebration 1905-2005 (Malta, PEG, 2005).

${ }^{17}$ Ibid.
} 
to administer vaccine to 120 million children under 5 years in one day: Rotarians, teachers, health workers and volunteers. From about 200,000 cases of polio each year, last year there was none.

Scicluna-Spiteri grew thousands of seedlings of trees for school children to plant over the island, but in the schools there seems to have been no sustained education about Brucellosis. There was no campaign to educate the public through the university, the newspapers or by the Church. The Catholic Church was active in controversial politics, but not in public health.

\section{Other Mediterranean countries}

The Maltese goat was much sought after as it was prolific, resistant to heat and dry conditions and gave high milk yields. Zammit said 'that it was the hardiest, the tamest, the best milking goat in existence' and a yield of five and a half litres of milk a day was not uncommon. Maltese herdsmen and their families were based in many Mediterranean countries, living closely with their goats and children in squalid and unhygienic conditions. ${ }^{18}$

\section{Gibraltar and North Africa}

Major Horrocks returned to Gibraltar where he made a retrospective survey of Brucellosis on the Rock. More than 400 cases had occurred in 1884 when there were 1,800 goats which grazed on the upper slopes. With the building of the Italian navy, the Rock was more heavily fortified, with large areas kept for water conservation: the area for the goats was much reduced. In 1905, Horrocks found only 254 goats still there. imported Spanish goats which had bred with the Maltese goats had evidence of infection. Others had been sold in Spain where goats had been exported to towns along the North African coast.

An outbreak of Brucellosis in Oran in 1906-7 was traced to contact with harness contaminated with urine from an infected mule. Laboratory experiments and frequent infections showed that simple contact could result in infection. In Algiers, Maltese tended the goats which were of Maltese, Spanish and mixed origins and a few were positive. A committee recommended that Maltese goats free from infection should be imported only to Algiers and Tunis. Later, a decree prohibited the importation or transit of goats or their meat or offal from Malta. Spanish goats from Western Algeria and Morocco brought the disease to Oran again (see above). The Institut Pasteur in Tunis produced a vaccine to immunise young goats. Brucellosis was confirmed in Tripoli in 1910: one case was a Maltese who drank only goats' milk. Brucellosis was eradicated in Port Said after World War I by culling all infected goats. There was of course another option - to remove all goats.

\section{Conclusion}

History may repeat as farce, but diseases recur with historical memories. The military may give orders, governments may pass laws, but authority may be subverted by intention or laziness. As major sources of transmission are removed, minor ones may also vanish only to recur, sometimes in unexpected circumstances. History may provide vital clues. Zammit's discovery that apparently healthy goats could suffer long infections and be carriers of the disease was 'one of the greatest advances ever made in the study of epidemiology. ${ }^{19}$

\footnotetext{
18 Wyatt , 'Brucellosis and Maltese goats in the Mediterranean,' Journal of Maltese History, 1 (2), 2009, 4-18.

19 W.J. Tulloch W.J. 'Sir David Bruce. An appreciation,' J R A M C, no.101, 1955, 81-90.
} 


\section{Figure 1}

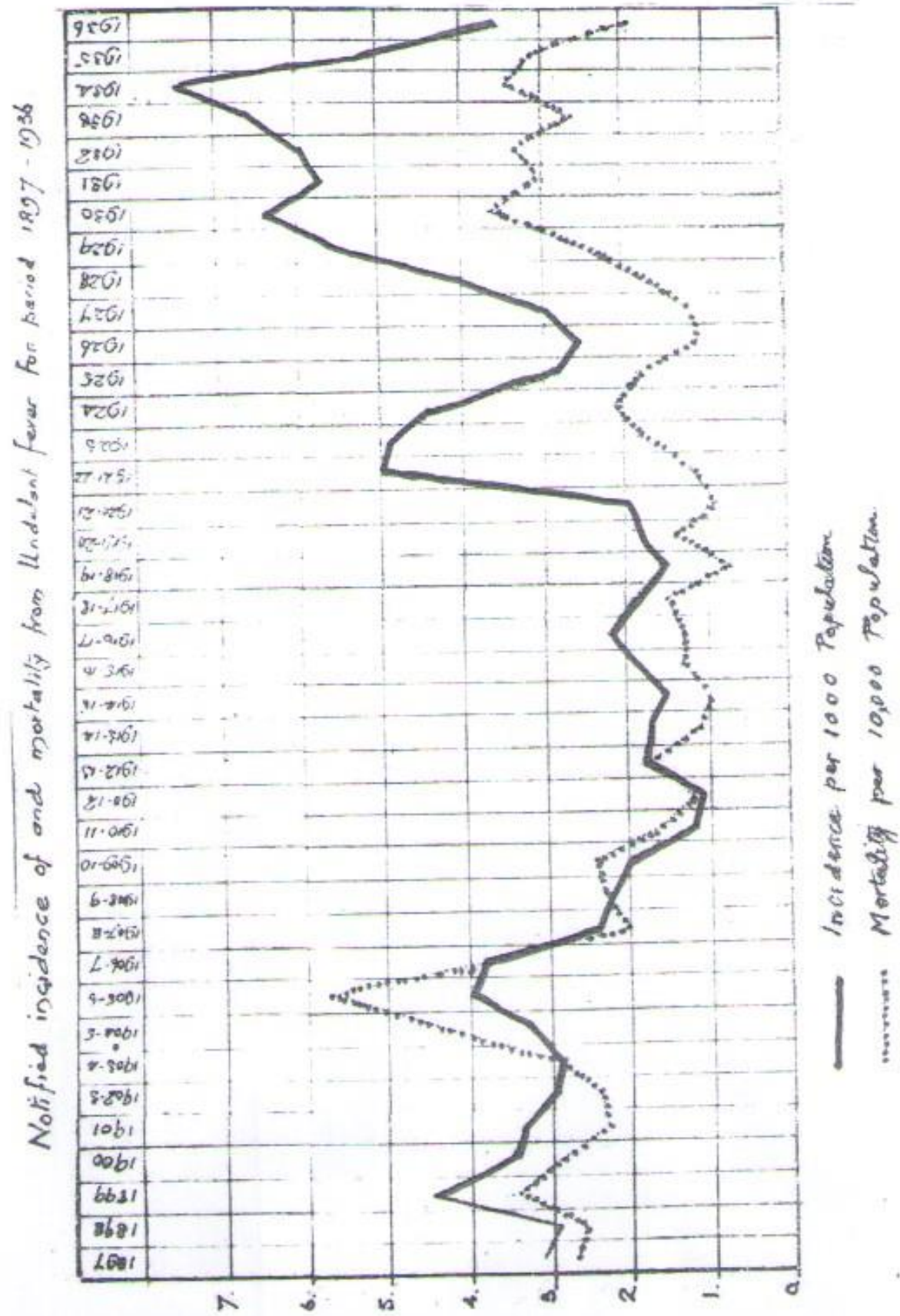


Journal of Maltese History, volume 5, number 1 (2016) 